\title{
Relationship between Consumer Motivation and the Gastronomic Experience of Olive Oil Tourism in Spain
}

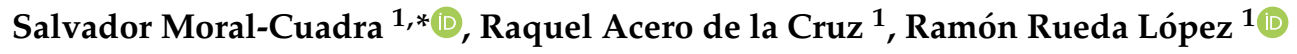 \\ and Enrique Salinas Cuadrado ${ }^{2}$ \\ 1 Departament of Statistic, Econometrics, Operational Research, Business Organization and Applied \\ Economics, University of Córdoba, 14071 Córdoba, Spain; pa2accrr@uco.es (R.A.d.l.C.); \\ ramon.rueda@uco.es (R.R.L.) \\ 2 Statistic Researcher at "Centro de Análisis y Prospectivas Turísticas de Córdoba”, 14071 Córdoba, Spain; \\ esalinascuadrado@outlook.com \\ * Correspondence: salvador.moral@uco.es
}

Received: 2 April 2020; Accepted: 18 May 2020; Published: 20 May 2020

\begin{abstract}
The rise of new tourist typologies as a result of the change in the motivations of tourists and the increasingly active awareness of the environment are making these new tourist activities more sustainable. The development of typologies such as oleotourism or, more globally, gastronomic tourism is formed as an engine of socio-economic development wherever it is inserted, being even more important and decisive if it develops in rural areas. This study is based on a model of structural equations based on minimum partial squares. A sample size of 414 surveys was used, all of which were collected in the oil mills and museums of the towns of Baena, Cabra, Luque and Montilla, all of which belong to the province of Córdoba, Spain. This study develops a model based on motivations and gastronomic experience resulting from the development of oleotourism in the rural areas of the province of Córdoba (Spain). Among the most noteworthy results it is worth highlighting the positive influence of motivations on the gastronomic experience of tourists. In addition, the predictive relevance of the model is demonstrated.
\end{abstract}

Keywords: rural; sustainability; oleotourism; gastronomy; motivation; Córdoba; olive oil

\section{Introduction}

Today's globalization is causing tourists' motivations to constantly change. Tourists are increasingly seeking new experiences that respond to their changing needs. Alternative typologies to sun and beach tourism are thus appearing, with each one built on a prism oriented to sustainability, whether from an economic, social or environmental point of view. Gastronomic tourism is positioned as a dynamizing activity not only in cities but also in rural locations. In fact, in many cases, it is the socioeconomic engine of the area [1]. This development has caused values such as social responsibility and the knowledge of cultural values to be enhanced [2].

The development of tourism activities linked to the endogenous resources existing in a rural area is a key element in the socioeconomic development of that area [3]. In fact, various studies address these resources' impact on investment in rural development at the infrastructure level $[4,5]$.

The development of activities linked to the rural environment is a boost to local economies. Tourist typologies other than those already known as sun and beach tourism, or cultural tourism, have already been exploited from the point of view of supply and demand. They have paved the way for the opening of new niches of demand that, when oriented through correct tools to promote the destination and the product, will cause great dynamism of the rural areas in which the activities are inserted. This is why gastronomic tourism, oleotourism, or other typologies focused on culinary aspects are 
important. The United Nations Educational, Scientific and Cultural Organization's (UNESCO) 2013 declaration of the Mediterranean Diet as an Intangible Cultural Heritage supports these typologies, which respond to the new and different motivations of tourists.

Tourism development in rural areas will depend on various factors of a political, economic and environmental nature [6]. This is the reason for the importance of tourist activities such as oleotourism and gastronomic tourism, as the development of these activities will affect rural areas where such activities are inserted. López-Guzmán et al. [7] also points out that other activities, such as gastronomic tourism, wine tourism or oil tourism, have emerged within the gastronomic field. The development of oleotourism is associated with the area of production and is now a part of the consumer experience $[2,8]$.

Today, growing interest in local cuisine has caused many destinations to focus their efforts on food as a central element of their tourism products [9]. Gastronomy is a reflection of the cultural identity of a specific geographical area. This symbiosis between tourism and gastronomy promotes local produce consumption, territorial development and sustainability [10].

The term "gastronomic tourism" is similar to that which other authors have used, such as "food tourism," "gourmet tourism," "food and wine tourism," "culinary tourism" or "tasting tourism" [11].

Various works have approached gastronomic tourism from different perspectives. Hjalager and Richards [12] analyzed a set of publications; Hall et al. [11] and Hall et al. [13] analyzed gastronomy and wine, respectively; and Long [14] addressed different works in which he analyzed the identity of gastronomic tourism. Jiménez-Beltrán et al. [15], on the other hand, completed a study that combined gastronomy, tourism and culture. Additionally, research such as Campón-Cerro et al. [16] concluded that a relationship exists between the management and marketing of tourist products of a gastronomic nature, as well as that this has a positive impact on the development of traditional rural economies.

Furthermore, Ellis et al. [17] established five aspects that can lead to defining the concept of gastronomic tourism (motivation, culture, authenticity, management and marketing, and destination). In this sense, and following the point that Kim et al. [18] posed, motivation can lead to the study of issues such as experiences or health-related issues. Second, we have culture. With López-Guzmán et al. [19], it is possible to place gastronomy as an inescapable part of the cultural heritage of the local or regional community. Third, authenticity is an elementary vector that guarantees, at the same time, both the development and the evolution of the gastronomy of a locality or region, as well as the possibility of promoting tourism in that area. Fourth, the management and marketing of the area addresses issues related to the fundamental aspects of the behavior of the tourist as a consumer. Finally, research covers the ties between the destination itself and the gastronomy of the place.

The Mediterranean basin (Spain, Italy and Greece, among others) is the main area of the exploitation of olive oil. Olive oil is also a key element within the aforementioned Mediterranean diet. According to data from the International Olive Council [20], Spain is responsible for $60 \%$ of the world's total olive oil production, with $80 \%$ of domestic production concentrated in the provinces of Jaén and Córdoba. It is so important that is called "liquid gold." In addition, the synergy of olive oil with wine [21] or with food [22] exists in these provinces.

Therefore, the objective of the study is to delve deeper into the relationship between the motivation of the tourist and the gastronomic experience acquired in the case of oleotourism in southern Spain, through a structural equations model.

\section{Theoretical Background}

The review of the scientific literature focused on the field of sustainability has been carried out through the two scientific bases of reference, Web of Science (WoS) and Scopus. Google Scholar was also used. The choice of these three databases derives from the aim to deepen as much as possible in the field of sustainability. The selection of keywords for the search for scientific literature was based on those related to sustainability and oleotourism and/or gastronomic tourism. Among other keywords, the following were included: "Sustainable", "sustainability", "rural", local community", "oleotourism", "gastronomic tourism", "sustainable development" and "sustainability farms" 
Both the aforementioned database search and the choice of keywords, and the subsequent selection of the scientific literature used were carried out establishing an initial time frame of the last five years, gradually expanding this time horizon in order to also collect the reference research in this field.

\section{Motivations and Gastronomic Experience}

The motivation that causes a tourist to come into contact with the local gastronomy of the place that he or she is visiting can have a dual origin: one motivation leads them to satisfy only their primary need to eat, and the other determines the time of choosing a particular tourist destination [23].

Following what López-Guzmán et al. [19] raised, the first of these reasons, to satisfy a primary need, can be classified as merely complementary. That means it does not entail a special incentive for the tourist. Hence, tourists who can be classified under this motivational behavior-those who show low, or very low, interest in the local gastronomic culture-ultimately decide to go to catering establishments that they can usually find in their localities, such as, in this case, various popular restaurant franchises.

This behavior should not lead one to ignore the behavior of this segment of tourists. Fields [24], for example, considered this motivation, the physiological need to eat, as the first in a group of four motivational behaviors. Thus, together with the aforementioned, Fields [24] pointed out three more: (1) cultural motivation and the need to discover through gastronomy both the destination and its surroundings, as well as its cultural heritage; (2) the interpersonal motivation from which the tourist tries to establish social relationships by discovering gastronomy; and (3) finally, a motivation focused on social recognition and approval through the pursuit of status and prestige. In the latter, the tourists seeks to differentiate themselves from their social and personal environment through the knowledge that enables them to know and value other realities and gastronomic cultures.

The researches that has covered the analysis of the motivations-and their possible dimensions - that cause tourists to value the gastronomy of the places they will visit have been diverse, and among them are those of [25-27]. As for the dimensions that can be valued as variables within motivation, Kim et al. [25] pointed to up to five: cultural experience, expectations, interpersonal relationships, sensory attractiveness and concern for health. The authors of [28] considered the following dimensions within the motivations: heritage, service, gastronomic environment, variety, availability and sensory impact.

More recently, Dimitrovski and Crepí-Vallbona [29] defined sensory appeal, the gastronomic experience at the destination, and the concern for health as the three main axes or dimensions under which to consider the gastronomic motivations of tourists. Finally, López-Guzmán et al. [19], in their research on experiences derived from gastronomic festivals, classified the motivations that cause a tourist to approach the gastronomy of the place that he or she visits into three categories: new gastronomic experiences, culture and the need for socialization.

The gastronomy developed in prominently rural areas consists of the presentation of traditionally cooked typical dishes where local and natural elements play a very important role [30]. Folgado-Fernández et al. [31] developed the concept of oleotourism as a set of activities that are developed around olive oil. The development of these activities is related to the local heritage, nature or culture that surrounds the rural territory where this activity is inserted [31]. In this sense, Balderas-Cejudo et al. [32] pointed out that gastronomy adds enormous added value to the tourist experience, leaving this associated with an increase in the quality of the trip for the tourist and resulting in an increase in the level of satisfaction.

The perception of gastronomic experiences is unique and generally quite subjective [33]. Quan and Wang [34] indicated that gastronomic experiences involve getting to know new ingredients and/or new ways of cooking the ingredients or consuming food. However, other elements are also essential in these experiences, such as the atmosphere of the establishment, as well as the possibility of chatting with owners and staff from the area about the dishes or the time spent enjoying the food [35]. Additionally, the gastronomic experience relates to three attributes [35]: first, the appearance of the food, where 
aspects such as texture, colour or plating up are valued; second, the situational factors, where the location of the establishment itself, the distribution of the tables or the environment are assessed; and third, the individual factors, where aspects such as the diner's own sensations or cognitive elements are collected.

On the other hand, as a result of what was mentioned by De Salvo et al. [36], the correct combination of the food and tourism industry is set up as an opportunity for two fundamental objectives: the first to achieve differentiation of the destination where the activity is inserted, and secondly, to generate induced profits resulting from the conservation and use of local production.

Another factor to take into consideration in the gastronomic experience is the set of emotions generated in diners. These emotions, which arise from the gastronomic experience, can be based on five variables [37]: the type and appearance of the product, the context, the activity and the memory. Following these authors, the gastronomic experience is not only a consequence of the direct aspects of the product, such as smell or taste, but also other variables, such as the visualization of the preparation of the food (as an activity), or the memory that this experience leaves.

Gastronomy can be deemed a tourist motivation [23] that causes tourists to move to different destinations to carry out different gastronomic practices [38]. Different studies establish a positive relationship between the motivations of the tourist and the gastronomic experience in a specific destination [38-40].

Following this review of the literature, the following hypothesis is proposed:

H1: Motivations positively influence the tourist's gastronomic experience.

The model of this investigation is presented in the Figure 1 below.

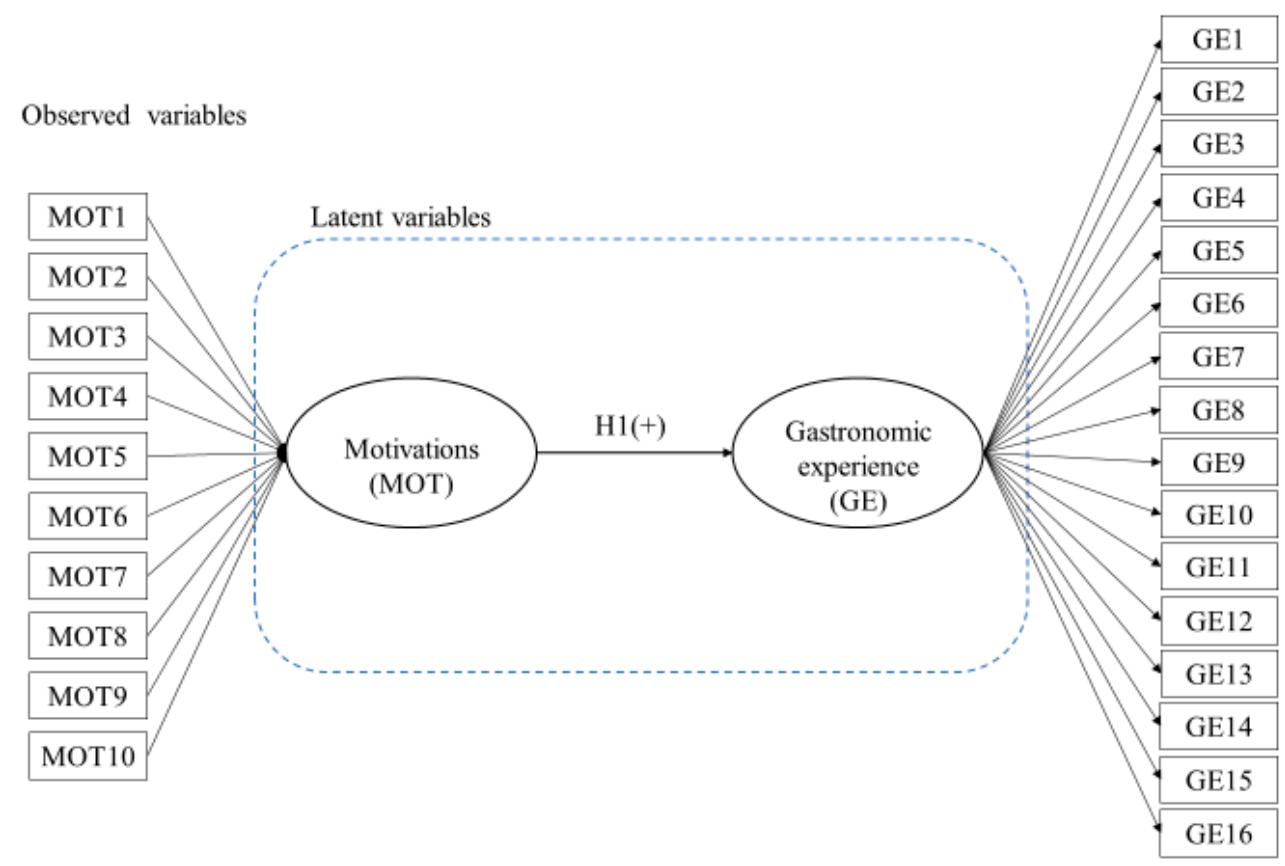

Figure 1. Investigation model.

\section{Materials and Methods}

Seeking to respond to one of the objectives set out in this investigation, a quantitative methodology based on primary sources was carried out, including a survey based on other previously published works $[38,41]$. The fieldwork was carried out between the months of March and October 2014, with surveys conducted in the olive oil mills of four locations in the province of Córdoba with great relevance in the oil production (Baena, Cabra, Luque and Montilla) (see Figure 2). 


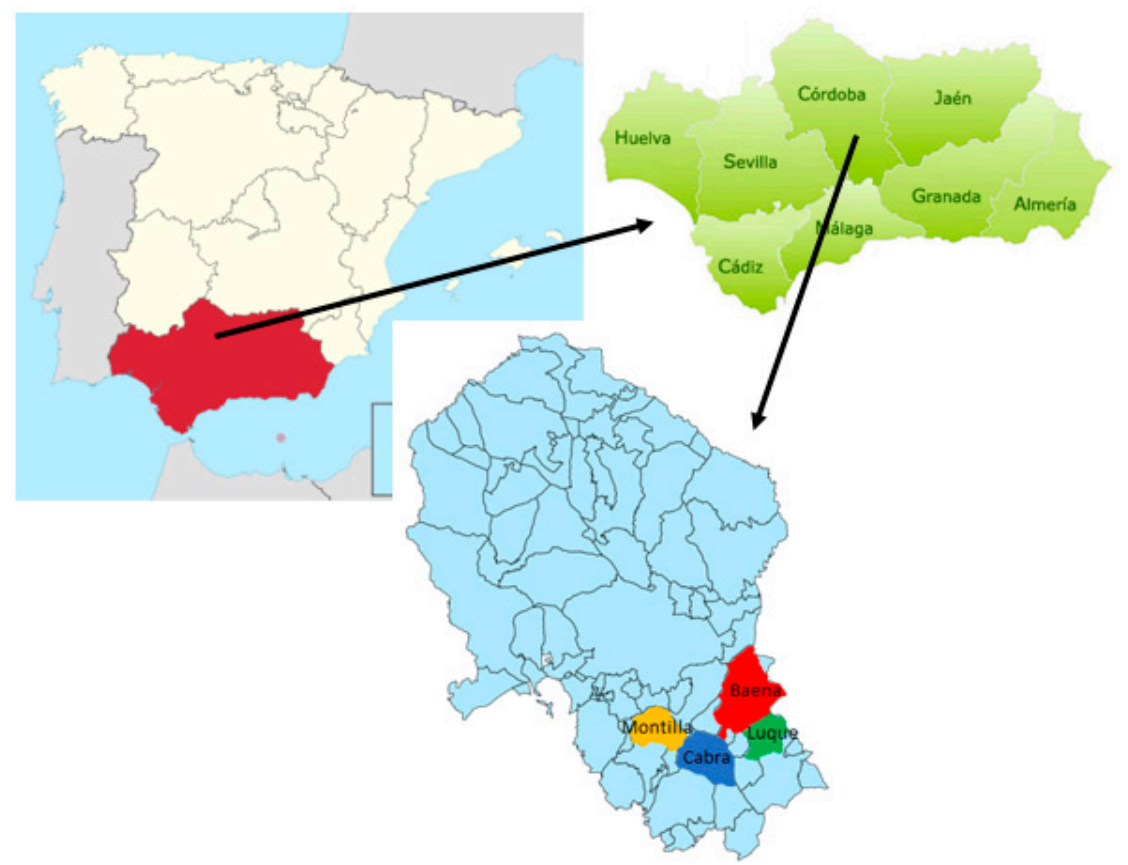

Figure 2. Location of the fieldwork.

The questionnaire was provided to tourists who visited the different mills and/or olive oil museums of the province of Córdoba. If no people are visiting a destination, it is not possible to establish an objective population using it, as has happened with previous studies [42,43]

The questionnaire used (see Table A1) was structured into three clearly differentiated parts: the first one asks questions concerning "whether you have previously visited that geographical area," the "time that you will remain in the geographical area during travel," "How do you travel," "Why have you chosen this geographical area as your destination," "types of activities performed during your stay," "if you are a regular consumer of olive oil" and "if you have purchased olive oil at the mill or museum of olive oil visited." All of these questions had closed answers, with only one of the options being deemed a possible answer; the second section addressed aspects such as "the main reasons for visiting the geographical area," "assessment of aspects related to the geographical area as a tourist destination" or the "assessment of the level of knowledge about olive oil." All questions included in this second block were asked through five-point Likert scales, from 1 (very low/very much disagree) to 5 (very good/very much agree). Finally, the third block included questions regarding the sociodemographic profile of the sample. In six questions, the following were addressed: "sex", "age", "level of study," "professional category," "city/country of origin" and, finally, "monthly rent."

The survey was anonymous, was in different languages and was available at a certain place and time [44]. The total number of surveys collected was 440 , although only a total of 414 were valid after a pre-filtering process.

The reliability of the questionnaire was verified using Cronbach's alpha, and the items whose corrected element-total ratio was less than 0.3 were deleted [45]. Cronbach alpha values greater than 0.70 were obtained for each construct, and a global alpha greater than 0.8 was obtained (see Table A2). It was not necessary to debug any of the items as the global Cronbach's alpha was 0.872 , well above the minimum threshold of 0.7 that the reference authors [46] indicate.

A model of structural equations (SEM), through the "partial least squares" methodology (hereinafter, PLS), supported this. The use of the PLS methodology applied to research in social sciences features a number of characteristics, such as the aforementioned non-assumption of sample distributions [47]. Another one of the characteristics is that compared with CBSEM (covariance-based models of structural equations), PLS avoids the problems of having inadmissible solutions derived from standardized loads greater than 1 [48]. PLS can also estimate structural models with relatively 
small samples [49]. Another feature is the possibility of estimating models with Mode A and Mode B measurements without any identification problem [47]. Finally, PLS presents robustness in the face of three inadequacies [50]: biased distributions, multicollinearity between constructs and between indicators, and an incorrect specification of the structural model resulting from the omission of some kind of return.

Models based on structural equations (SEM) have been used to measure the impact of motivations on the gastronomic experience. Hence, another reason why PLS is used is due to the explanatory nature of this investigation, with PLS being one of the most widely accepted tools for achieving this purpose [51]. To verify the measurement model and structural model presented below, as well as the preliminary analysis performed, SPSS (v.24) and SmartPLS (v3.2.8) were used.

First, the reliability of the global model was assessed. Second, the reliability and validity of the measurement model were assessed, with an assessment carried out at the individual or item level and at the construct level. Finally, the third of the phases involved the evaluation of the structural model and the assumptions raised in the model.

\section{Results}

\subsection{Sociodemographic Profile}

The following Table 1 discusses the results obtained from the sociodemographic profile of the sample.

Table 1. Sociodemographic profile.

\begin{tabular}{llllll}
\hline Variable & & Percentage & Variable & & Percentage \\
\hline Gender & Male & $43.1 \%$ & Education level & Primary & $12.6 \%$ \\
$\mathrm{~N}=394$ & Female & $53.9 \%$ & $\mathrm{~N}=388$ & Secondary & $35.1 \%$ \\
& & & University & $52.3 \%$ \\
& Less than 30 & $14.6 \%$ & & Spain & $43.1 \%$ \\
Age & 30-39 years & $5.1 \%$ & Country & France & $28.2 \%$ \\
$\mathrm{~N}=391$ & 40-49 years & $9.7 \%$ & $\mathrm{~N}=401$ & UK & $11.7 \%$ \\
& 50-59 years & $16.9 \%$ & & Germany & $6.2 \%$ \\
& More than 60 & $53.7 \%$ & & USA & $3.2 \%$ \\
& & & & Others & $7.6 \%$ \\
& Less than $700 \$$ & $6.0 \%$ & & Retired & $40.4 \%$ \\
Income & 700-1000\$ & $6.3 \%$ & Liberal & $16.1 \%$ \\
$\mathrm{~N}=333$ & 1001-1500\$ & $23.7 \%$ & $\mathrm{~N}=386$ & professional & $13.7 \%$ \\
& 1501-2500\$ & $32.7 \%$ & & Full time job & $13.0 \%$ \\
& More than & $31.2 \%$ & & Student & $10.1 \%$ \\
& 2500\$ & & & Public worker & $6.7 \%$ \\
\hline
\end{tabular}

Source: own elaboration.

The tourists' sociodemographic profile was majority female (53.9\%), with an age greater than 60 years in more than half of cases $(53.7 \%)$, with a higher level of education $(52.3 \%)$, with more than $40.4 \%$ of cases in retirement and with a monthly income of more than 2500 euros in one third of cases $(31.2 \%)$. Finally, in terms of nationality, $43.1 \%$ were Spanish, followed by French (28.2\%), British (11.7\%) and Germans (6.2\%).

\subsection{Descriptive Analysis}

Descriptive statistics are shown in Table 2. It should be noted that the most valued indicators of motivations were "learning about the world of olive oil" (3.68 out of 5) and "eating and drinking traditional products from the area" (3.49 out of 5). On the other hand, the least valued motivations were those aimed at "visiting friends and/or family members" (1.83 out of 5) and "work-related reasons" (1.74 out of 5$)$. As for the best-rated indicators of the gastronomic experience we found "hospitality 
and treatment" (4.11 out of 5) and "food" (3.85 out of 5), while the least valued were "commercial area" (3.00 out of 5$)$ and "sports activities" (2.59 out of 5$)$.

Table 2. Descriptive statistics.

\begin{tabular}{|c|c|c|c|c|c|}
\hline Indicator & Average & Standard Deviation & Asymmetry & Kurtosis & Normal K-S Test (Sig.) \\
\hline \multicolumn{6}{|l|}{ Motivations } \\
\hline MOT1: To taste the different types of olive oil & 2.94 & 1.489 & 0.017 & -1.407 & $0.160\left(0.000^{c}\right)$ \\
\hline MOT2: To buy olive oil in a factory & 2.65 & 1.462 & 0.269 & -1.326 & $0.204\left(0.000^{c}\right)$ \\
\hline MOT3: To learn about the olive oil world & 3.68 & 1.370 & -0.700 & -0.743 & $0.227\left(0.000^{c}\right)$ \\
\hline $\begin{array}{l}\text { MOT4: To eat and drink traditional products } \\
\text { of this zone }\end{array}$ & 3.49 & 1.294 & -0.537 & -0.735 & $0.203\left(0.000^{\mathrm{c}}\right)$ \\
\hline MOT5: Entertainment & 3.36 & 1.340 & -0.375 & -1.000 & $0.187\left(0.000^{\mathrm{c}}\right)$ \\
\hline MOT6: Relax & 3.01 & 1.341 & -0.041 & -1.115 & $0.144\left(0.000^{c}\right)$ \\
\hline MOT7: To spent a day outdoors & 2.96 & 1.472 & -0.006 & -1.384 & $0.164\left(0.000^{c}\right)$ \\
\hline MOT8: To know the geographical area & 3.76 & 1.360 & -0.834 & -0.561 & $0.231\left(0.000^{c}\right)$ \\
\hline MOT9: To visit friends and/or family & 1.83 & 1.478 & 1.458 & 0.384 & $0.432\left(0.000^{c}\right)$ \\
\hline MOT10: Work reasons & 1.74 & 1.342 & 1.595 & 0.987 & $0.429\left(0.000^{\mathrm{c}}\right)$ \\
\hline \multicolumn{6}{|l|}{ Gastronomic experience } \\
\hline GE1: Travel price & 3.43 & 1.127 & -0.278 & 0.987 & $0.203\left(0.000^{\mathrm{c}}\right)$ \\
\hline GE2: Hospitality & 4.11 & 1.038 & -1.239 & -0.455 & $0.251\left(0.000^{c}\right)$ \\
\hline GE3: Environment conservation & 3.78 & 1.080 & -0.543 & 1.156 & $0.201\left(0.000^{\mathrm{c}}\right)$ \\
\hline GE4: Information and signage & 3.48 & 1.117 & -0.357 & -0.500 & $0.175\left(0.000^{c}\right)$ \\
\hline GE5: Olive oil factories & 3.62 & 1.139 & -0.572 & -0.479 & $0.211\left(0.000^{\mathrm{c}}\right)$ \\
\hline GE6: Accommodation & 3.62 & 1.140 & -0.608 & -0.376 & $0.213\left(0.000^{\mathrm{c}}\right)$ \\
\hline GE7: Restoration & 3.68 & 0.994 & -0.470 & -0.285 & $0.224\left(0.000^{\mathrm{c}}\right)$ \\
\hline GE8: Communications & 3.35 & 1.146 & -0.275 & -0.221 & $0.168\left(0.000^{\mathrm{c}}\right)$ \\
\hline GE9: Public security & 3.67 & 1.092 & -0.612 & -0.604 & $0.220\left(0.000^{c}\right)$ \\
\hline GE10: Cleanness & 3.74 & 1.091 & -0.736 & -0.194 & $0.232\left(0.000^{c}\right)$ \\
\hline GE11: Telecommunications & 3.26 & 1.166 & -0.252 & 0.029 & $0.177\left(0.000^{\mathrm{c}}\right)$ \\
\hline GE12: Feeding & 3.85 & 1.029 & -0.719 & -0.632 & $0.222\left(0.000^{\mathrm{c}}\right)$ \\
\hline GE13: Spectacles and cultural activities & 3.78 & 1.090 & -0.730 & 0.060 & $0.233\left(0.000^{\mathrm{c}}\right)$ \\
\hline G14: Commercial area & 3.00 & 1.211 & -0.079 & -0.070 & $0.182\left(0.000^{c}\right)$ \\
\hline GE15: Ecology & 3.46 & 1.045 & -0.309 & -0.805 & $0.213\left(0.000^{\mathrm{c}}\right)$ \\
\hline GE16: Sport activities & 2.59 & 1.296 & 0.341 & -0.538 & $0.163\left(0.000^{c}\right)$ \\
\hline
\end{tabular}

Notes: ${ }^{c}=$ correction of significance of Lilliefors; source: own elaboration.

The results obtained from the Kolmogorov-Smirnov test allowed us to test the normality of the variables. After analyzing the significance, the thesis of normality was rejected, and thus the variables do not follow a normal distribution. These results only endorse what could already be seen through the results obtained from kurtosis and distribution asymmetry.

\subsection{Analysis of the Validity and Reliability of the Global Model}

Authors such as [48] point out that model adjustment measures should be the starting point for model valuation. Approximate adjustment measures are used for such methodologies [52]. In this sense, the standardized root mean square residual (SRMR) is used to mediate the adjustment of the global model, considering a good fit for SRMR values smaller than 0.8 [53] or 0.10 [54]. The SRMR of the model is 0.042 , thus indicating a good fit of the overall model.

\subsection{Analysis of the Reliability and Validity of the Measurement Model}

For this second phase, the analysis was carried out with a focus on differentiating between composite mode A (gastronomic experience) and composite mode B (motivations).

Within the individual analysis of the mode A composite, the items were measured through their factorial loads, accepting values equal to or greater than 0.707 [55]. Several indicators relating to the compound "Gastronomic experience" were eliminated by not exceeding the minimum threshold required. The explanation of why a factorial load limit was set at 0.707 is due to the communality of the indicator $\left(\lambda^{2}\right)$, which expresses the amount of variance of an observable indicator or variable that is explained by the construct to which it belongs [56]. Thus, all observable variables with loads greater than 0.707 share a greater variance with their construct than with the variance due to error. In the present model, on the other hand, assuming that the mode B composite items are not correlated and are error-free [57], the evaluation of these was carried out on two levels [47]: through the weights, 
indicating these to the extent that each of them contribute to the formation of their respective construct; and through the assessment of multicollinearity (valuation via variance inflation factor test-VIF) [58], where VIF values greater than 3.3 [59] would be symptomatic of high collinearity. The existence of high multicollinearity between indicators would generate unstable estimates.

Table 3 shows individual validity and reliability analyses.

Table 3. Individual validity and reliability of items.

\begin{tabular}{|c|c|c|c|c|}
\hline & Loadings & Communality & Weights (Sig.) & VIF \\
\hline \multicolumn{5}{|l|}{ Gastronomic experience-Composite Mode A } \\
\hline Environment conservation & 0.715 & 0.511 & & \\
\hline Restoration & 0.726 & 0.527 & & \\
\hline Public safety & 0.705 & 0.497 & & \\
\hline Cleanness & 0.715 & 0.511 & & \\
\hline Telecommunications & 0.715 & 0.511 & & \\
\hline Feeding & 0.743 & 0.552 & & \\
\hline \multicolumn{5}{|l|}{ Motivations-Composite Mode B } \\
\hline To taste the different types of olive oil & & & $-0.055(0.268)$ & 1.487 \\
\hline To buy olive oil in a factory & & & $0.143(0.047)$ & 1.444 \\
\hline To learn about the olive oil world & & & $0.344(0.000)$ & 1.273 \\
\hline To eat and drink traditional products of this zone & & & $0.441(0.000)$ & 1.387 \\
\hline Entertainment & & & $0.119(0.119)$ & 1.659 \\
\hline Relax & & & $0.002(0.493)$ & 1.951 \\
\hline To spent a day outdoors & & & $0.297(0.001)$ & 1.684 \\
\hline To know the geographical area & & & $0.157(0.030)$ & 1.270 \\
\hline To visit friends and/or family & & & $0.234(0.007)$ & 1.148 \\
\hline Work reasons & & & $-0.201(0.000)$ & 1.667 \\
\hline
\end{tabular}

Source: own elaboration.

The maintenance of the non-significant indicators is justified by what Roberts and Thatcher [59] mentioned. They stated that "even if an item contributes little to the explained variance of the construct, it must be included in the measurement model", because deleting an indicator involves removing a portion of the formation of that construct.

At the construct level, reliability and validity analyses were carried out through internal consistency, determining through the degree of rigor which observable variables measure the same latent or compound variable. This was measured via the composite reliability of Dijkstra-Henseler (Rho_A), which is considered to be the only consistent measure of reliability [60], differing from Cronbach's alpha insofar as the Rho_A does not assume that all indicators receive identical weighting [61]. Additionally, through convergent validity, measured through the average variance extracted (AVE) [62], we quantified the amount of variance that a compound obtains from its indicators or variables observable in relation to the amount of variance due to the error of measurement. The minimum requirement levels for composite reliability and the mean extracted variance are 0.7 and 0.5 , respectively [52]. Finally, the convergent validity tells us how a construct is different from other constructs. The Fornell-Larcker test tells us the extent to which the model complies with the discriminatory validity [62]. For this to be possible, the square root of the AVE of a construct must be greater than the correlation that this construct has with any other model construct (Table 4).

Table 4. Construct and discriminant validity and reliability.

\begin{tabular}{lcccc}
\hline & (1) & (2) & Rho_A & AVE \\
\hline (1) Gastronomic experience & 0.720 & & 0.817 & 0.519 \\
(2) Motivations & 0.521 & 1.000 & n/a \\
\hline
\end{tabular}

Notes: n/a: not applicable; source: own elaboration; Rho_A: composite reliability of Dijkstra-Henseler; AVE: average variance extracted.

As a result of the results shown in the tables above, optimum validity and reliability were observed both at the individual level and at the construct level. 


\subsection{Structural Model Validity Analysis}

The existence of collinearity between the various constructs that make up the model were analyzed through the aforementioned variance factor inflation test, although the levels are more lax, with the minimum threshold for the existence of multicollinearity being 5 (VIF > 5) [55]. In this model, the VIF is set to a value of VIF $=1000$, and thus no multicollinearity problems exist between constructs.

In relation to the predictive power and predictive capacity of the model (Table 5), the coefficient of determination $\left(\mathrm{R}^{2}\right)$ and Stone-Geisser test $\left(\mathrm{Q}^{2}\right)$ were used, respectively. Chin [61] established different values in relation to the coefficient of determination obtained. Thus, a moderate predictive power is between 0.33 and 0.19 . In this model, $R^{2}$ is 0.271 , so it is within the reference values for a predictive power of the moderate model.

Table 5. Predictive power and relevance.

\begin{tabular}{ccc}
\hline & $\mathbf{R}^{2}$ & $\mathbf{Q}^{2}$ \\
\hline Gastronomic experience & 0.271 & 0.125 \\
\hline \multicolumn{2}{c}{ Source: own elaboration. }
\end{tabular}

In terms of predictive capacity, values greater than zero $(0)[63,64]$ of $\mathrm{Q}^{2}$ would indicate the existence of the predictive capacity of the model. In this research, a $Q^{2}$ of 0.125 has been obtained and is considered to be a more than acceptable predictive capacity. In this sense, and in reference to the variance explained, it was calculated through the multiplication of the path coefficient and the correlation between the variables. Thus, the compound motivations contribute to explaining $27.14 \%$ of the variability of the compound gastronomic experience $(b=0.521 *$ correlation $=0.521=0.2714)$.

For the purpose of checking the degree of the relationship of the hypothesized constructs, a bootstrapping of 10,000 samples [65] was performed, obtaining the $t$ statistics and confidence intervals related to the hypothesis contrast (Table 6).

Table 6. Hypotheses.

\begin{tabular}{|c|c|c|c|c|c|c|}
\hline \multirow{2}{*}{ Hypotheses } & \multirow{2}{*}{ Suggested Effect } & \multirow{2}{*}{ Coeff. Path ( $\beta$ ) } & \multirow{2}{*}{ t Value } & \multicolumn{2}{|c|}{ Confidence Interval (95\%) } & \multirow{2}{*}{ Supported? } \\
\hline & & & & $5 \%$ & $95 \%$ & \\
\hline $\begin{array}{l}\text { H1: Motivations } \rightarrow \\
\text { Gastronomic experience }\end{array}$ & $(+)$ & $0.521^{* * *}$ & 14.562 & 0.444 & 0.564 & Yes \\
\hline
\end{tabular}

To the already proven goodness of fit measured through the SRMR (SRMR $=0.042$ ), a correct individual reliability of the items that make up the model was added, although it was necessary to suppress some indicators because it had loads much lower than allowed. No multicollinearity problems were found between indicators and between the constructs that make up the model. In terms of the validity and reliability of the constructs, values were obtained above the reference values, in terms of both composite reliability (Rho_A $=0.817$ ) and convergent validity $($ AVE $=0.519)$.

The final structural model is presented in Figure 3. 
Observed variables

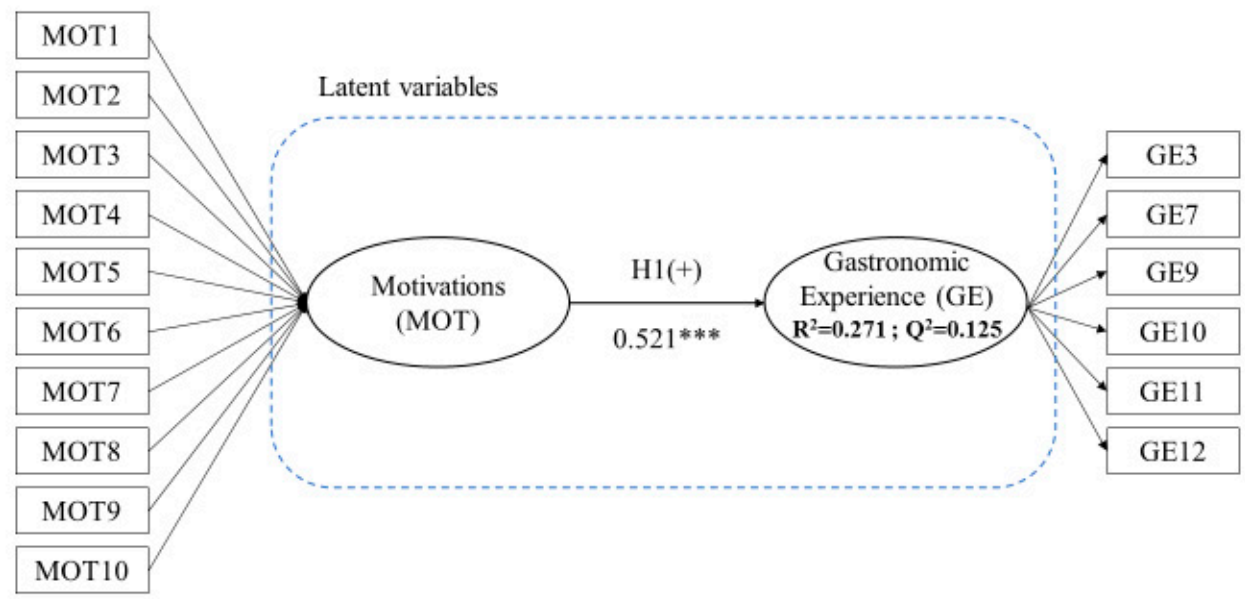

Figure 3. Structural model. Notes: ${ }^{* *} p<0.001 ;{ }^{* *} p<0.01$; ${ }^{*} p<0.05$; ns.: not significant. $\mathrm{t}(0.05 ; 4999)=1.645$; $\mathrm{t}(0.01 ; 4999)=2.327 ; \mathrm{t}(0.001 ; 4999)=3.092$.

\section{Discussion}

The motivations that lead to one's desire to taste the gastronomy of a certain destination are part of the tourist experience [40]. Gastronomic tourism refers to a typology that is constantly growing [38].

Among the best-valued elements of the gastronomic experiences of tourists are those directly related to the environment in which oleotourism activity is inserted. The hospitality and the treatment, as well as the conservation of the environment, are worth noting. These elements are key to the formation of an adequate tourist product that, hand in hand with olive oil, generates a unique experience for tourists.

The proposed structural model highlights the positive influence of motivations on the gastronomic experience, supporting previous research that also established this positive influence [38-40]. In addition, this positive gastronomic experience results in higher levels of satisfaction on the part of the tourist, which could generate behaviors to bring the tourist back to the destination [40].

In line with the results obtained, the development of a positive gastronomic experience is formed as a catalyst for the tourist experience, giving it a greater added value that results in an increase in the level of satisfaction of the tourist [32].

\section{Conclusions}

The new attitudes and motivations that tourists experience today are marking the emergence of new tourist typologies that respond to these new needs. In this sense, this emergence of activities is increasingly being framed in rural development areas, with this migration being the key tourist activity for the socioeconomic development of the area. The development of activities such as oleotourism or gastronomic tourism is carried out under the prism of sustainability, considering the economic, social and environmental components.

The tourism-gastronomy binomial is now key as a result of the growing interest in culinary elements as tourist products. Gastronomy is formed as a cultural element, with its own identity, that represents the idiosyncrasies of a particular place. The use of the aforementioned binomial is key in the development of not only the economic but also the social and environmental aspects of the area in which it is inserted, taking advantage of elements of the area, and considering the correct development of the sustainable activities.

Through activities such as oleotourism, we must seek the sustainability of the territory through the consumption and purchase of olive oil in the areas where it is produced. This would lead to domestic consumption, which would entail the socioeconomic development of the territory while 
achieving wealth creation and the resulting added value in the local territory. The development of local businesses is key to the establishment of a business network that will lead to the aforementioned creation of wealth and value, which is already being done in other rural areas spread around the world [10,66-68].

On the other hand, the statistical study carried out shows the positive influence of the motivations on the subsequent gastronomic experience of the tourist, in line with previous studies [34]. In addition, the relevance and predictive power of the model are worth highlighting, according to the indexes used for this purpose.

Several places where field research has been developed have been presented in this study. The sites are relatively close, so the development of rural gastronomic routes could be one of the activities to develop, taking advantage of the adjoining infrastructures. The correct combination of public and/or private bodies is key to establishing the strategies to be carried out to preserve the value of rural areas as new gastronomic destinations.

In line with the above, it becomes indispensable that both local authorities and private companies work together, establishing synergies for the development of rural areas as new gastronomic destinations. The role of the local community also becomes indispensable, as it is a very important asset in the development of gastronomic activities such as oleotourism. In addition, the fact that most of the areas where olive oil is produced are rural must be taken advantage of and enhanced, so the promotion and value of museums and mills are key to the formation of tourist products that benefit the local populations where the activity is inserted.

We must not forget the development of these activities from a sustainable point of view, so that there is a social and economic development of the area while generating the minimum possible harm in the environmental spheres. In this final task, public and/or private bodies once again play a key role in the establishment of sustainable strategies.

In relation to limitations, it would have been interesting to carry out the study on a wider time horizon as well as to reach all stakeholders (local population, local companies, public/private bodies, etc.). This would help us to know firsthand the opinions of both demand and supply stakeholders so as to undertake strategies for the correct promotion of these activities in rural areas. This would energize the most depressed rural areas and give them greater weight from an economic and social point of view. The correct knowledge of the motivations would generate niches to occupy, and with well-defined strategies, this would make gastronomic activities more attractive. Gastronomy's inherent cultural component would support all of this, reinforced by the appointment of the Mediterranean diet in 2013 as an Intangible Cultural Heritage according to UNESCO.

Regarding future lines of research, the plan is to broaden the time horizon of fieldwork, thus reaching interest groups not analyzed so far, such as local public bodies and, above all, the local community. Another element that arises in a time horizon not too far away is the extension of the study to other rural areas of the province of Cordoba, focusing on its gastronomy.

Author Contributions: Conceptualization: R.A.d.1.C. and R.R.L.; Methodology: S.M.-C.; Software: S.M.-C. and E.S.C.; Validation: E.S.C.; Formal analysis: S.M.-C. and R.R.L.; Investigation: S.M.-C., R.A.d.l.C. and R.R.L.; Resources: E.S.C.; Data curation: R.A.d.l.C.; Writing-original draft preparation: R.A.d.l.C. and E.S.C.; Writing-review and editing: S.M.-C.; Supervision: S.M.-C. and R.A.d.l.C.; Project administration: S.M.-C. All authors have read and agree to the published version of the manuscript.

Funding: This research received no external funding.

Conflicts of Interest: The authors declare no conflict of interest. 


\section{Appendix A}

Table A1. Variables, measurement of model variables and sociodemographic profile.

\begin{tabular}{ll}
\hline \multicolumn{1}{c}{ Variable/Items } & \multicolumn{1}{c}{ Measurement } \\
\hline Have you ever been in this geographical area? & Never; 1-3 times; More than 3 times \\
How much time will you stay in this geographical area? & 1 day (no sleep); 2 days (1 night); 3-7 days; More than one week \\
How do you travel? & Alone; friends/work mates; partner; partner and children; \\
& with children \\
Why did you choose this geographical area as a & Recommendation agency; recommendation by friends; by myself; \\
tourist destination? & tourists brochures; mass media publicity; clubs and associations; \\
& internet; work \\
What type of activities did you do during your trip? & Rural tourism; adventure tourism; olive oil tourism; olive oil and \\
& gastronomic tourism; cultural tourism; business tourism \\
Do you usually consume olive oil? & No; everyday; more than one time per week; only once \\
If you bought olive oil in the factory, what was the reason? & per week; rarely \\
& For myself; a gift; for myself and to make a gift \\
\hline
\end{tabular}

\section{Motivations}

To taste the different types of olive oil

To buy olive oil in a factory

To learn about the olive oil world

To eat and drink traditional products of this zone

Entertainment

Relax

To spent a day outdoors

To know the geographical area

To visit friends and/or family

Work reasons

1: Very low/strongly disagree
2: Low/disagree
3: Neutral
4. High/agree
5: Very high/Strongly agree

$\begin{array}{ll}\text { Gastronomic experience } & \\ \text { Travel price } & \\ \text { Hospitality } & \\ \text { Environment conservation } & \\ \text { Information and signage } & \\ \text { Olive oil factories } & \\ \text { Accommodation } & \text { 1: Very low/strongly disagree } \\ \text { Restoration } & \text { 2: Low/disagree } \\ \text { Communications } & \text { 3: Neutral } \\ \text { Public safety } & \text { 4. High/agree } \\ \text { Cleanness } & \text { 5: Very high/strongly agree } \\ \text { Telecommunications } & \end{array}$

Feeding

Spectacles and cultural activities

Commercial areas

Ecology

Sport activities

\section{Sociodemographic Profile}

Gender

Age

Academic level

Professional category

Income

Country

Dichotomic (male/female)

Interval (less than 30; 30-39 years old; 40-49 years old;

$50-59$ years old; 60 years old or more)

Multi-response (elementary; secondary; university)

Freelance; full-time job; public worker; student; retired; household

Less than 700 EUR / month; from 700 to 1000 EUR / month;

from 1001 to $1500 \mathrm{EUR} /$ month; from 1501 to $2500 \mathrm{EUR} / \mathrm{month}$; more than 2500 EUR/month 
Table A2. Preliminary data analysis results (Cronbach's alpha).

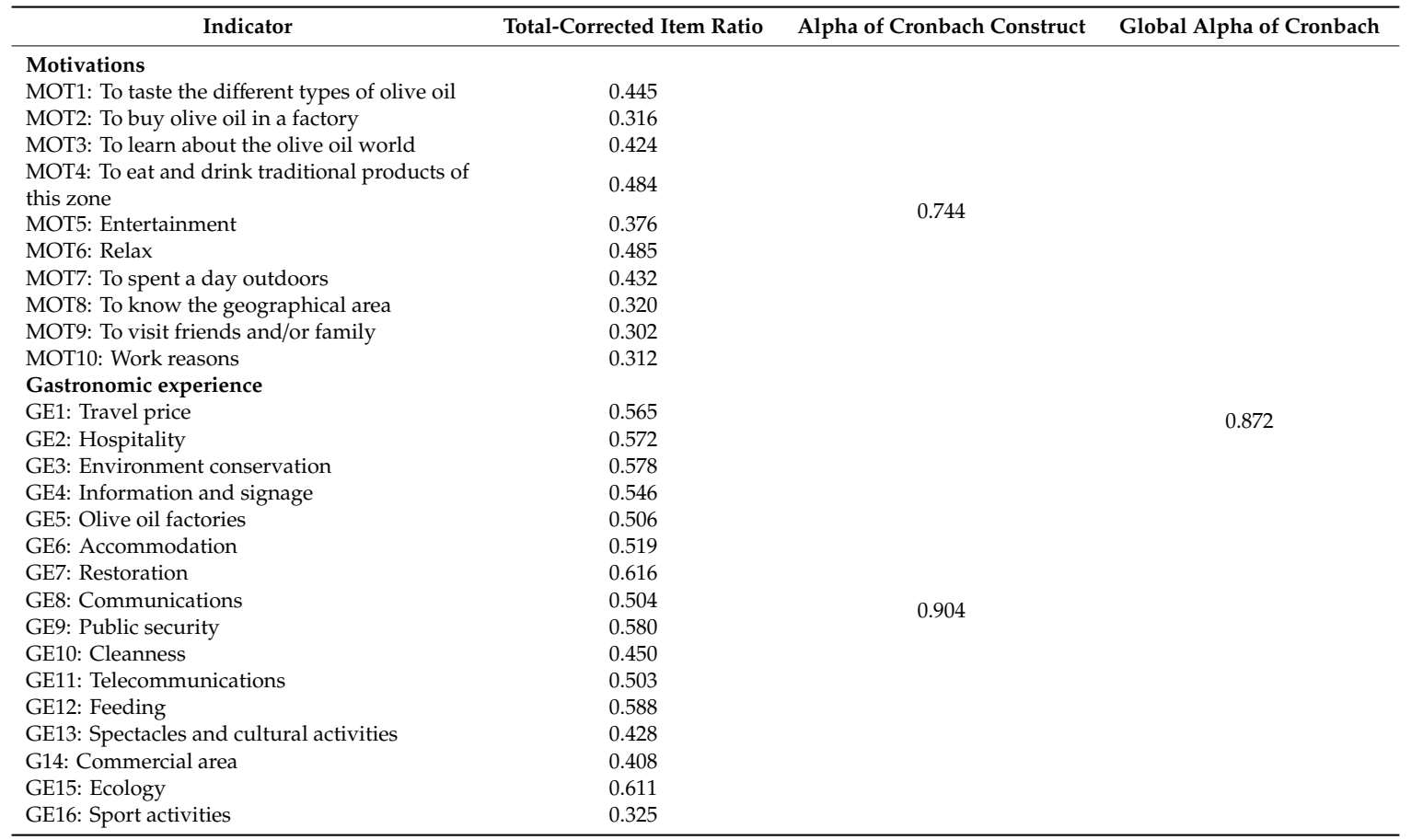

Source: own elaboration.

\section{References}

1. López-Guzmán, T.; Sánchez-Cañizares, S. Culinary tourism in Cordoba (Spain). Br. Food J. 2012, 54, 168-179. [CrossRef]

2. Aybar, R. Proyecto Oleoturismo: Una red Europea para la Promoción de la Cultura del Olivo; Diputación Provincial de Jaén: Jaén, Spain, 2004.

3. Beeton, S. Community Development through Tourism; Land Links: Collingwood, Australia, 2006.

4. Duffy-Deno, K.T.; Eberts, R.W. Public infrastructure and regional economic development: A simultaneous equations approach. J. Urban Econ. 1991, 30, 329-343. [CrossRef]

5. Pavel, A.; Moldovan, O. Determining local economic development in the rural areas of Romania. Exploring the role of exogenous factor. Sustainability 2019, 11, 282. [CrossRef]

6. López-Guzmán, T.; Sánchez-Cañizares, S. Community-based tourism and wealth generation in developing countries. A study of case in El Salvador. Rev. Estud. Coop. 2009, 99, 85-103.

7. López-Guzmán, T.; García, J.R.; Rodríguez, A.V. Revisión de la literatura científica sobre enoturismo en España. Cuad. Tur. 2013, 32, 171-188.

8. Guerra, I.R.; Moreno, V.M.; López, V.M.M. El oleoturismo como atractivo turístico en el medio rural español. Pap. Tur. 2011, 49-50, 89-103.

9. Karim, S.A.; Chi, C.G.-Q. Culinary tourism as a destination attraction: An empirical examination of destinations' food image. J. Hosp. Mark. Manag. 2010, 19, 531-555. [CrossRef]

10. Lee, J.S.; McCole, D.; Holecek, D. Exploring winery visitors in the emerging regions of North Central United States. Sustainability 2020, 12, 1642. [CrossRef]

11. Hall, M.C.; Sharples, L.; Mitchell, R.; Macionis, N.; Cambourne, B. Food Tourism around the World; Butterworth-Heinemann: Oxford, UK, 2003.

12. Hjalager, A.-M.; Richards, G. Tourism and Gastronomy; Routledge: London, UK, 2002.

13. Hall, C.M.; Sharples, L.; Cambourne, B.; Macionis, N. Wine Tourism around the World: Development, Management and Markets; Elsevier: Oxford, UK, 2000.

14. Long, L.M. Culinary tourism: A folkloristic on eating and otherness. In Culinary Tourism; Long, L.M., Ed.; The University Press of Kentucky: Lexington, KY, USA, 2004; pp. 20-50. 
15. Jiménez Beltrán, J.; López-Guzmán, T.; Santa-Cruz, F.G. Gastronomy and tourism: Profile and motivation of international tourism in the city of Córdoba, Spain. J. Culin. Sci. Technol. 2016, 14, 350-366. [CrossRef]

16. Campón-Cerro, A.M.; Hernández-Mogollón, J.M.; Alves, H. Sustainable improvement of competitiveness in rural tourism destinations: The quest for tourist loyalty in Spain. J. Destin. Mark. Manag. 2019, 6, 252-266. [CrossRef]

17. Ellis, A.; Park, E.; Kim, S.; Yeoman, I. What is food tourism? Tour. Manag. 2018, 68, 250-263. [CrossRef]

18. Kim, Y.G.; Eves, A.; Scarles, C. Empirical verification of a conceptual model of local consumption at a tourist destination. Int. J. Hosp. Manag. 2013, 33, 484-489. [CrossRef]

19. López-Guzmán, T.; Uribe-Lotero, C.P.; Pérez-Gálvez, J.C.; Ríos-Rivera, I. Gastronomic festivals: Attitude, motivation and satisfaction of the tourist. Br. Food J. 2017, 119, 267-283. [CrossRef]

20. Consejo Oleícola Internacional. Producción de Aceite de Oliva; Servicio de Publicaciones: Madrid, Spain, 2013.

21. Vargas-Sánchez, A.; Bueno, N.P.; Mejía, M.Á.P.; Ligero, F.R. Turismo enológico: Comportamiento del turista y percepción de la población residente. Pap. Tur. 2012, 43-44, 97-111.

22. Morales Fernández, E. Denominaciones de Origen Protegidas (DOP) y turismo gastronómico: Una relación simbiótica en Andalucía. Gran Tour 2012, 6, 101-121.

23. Kim, S.; Park, E.; Lamb, D. Extraordinary or ordinary? Food tourism motivations of Japanese domestic noodle tourists. Tour. Manag. Perspect. 2019, 29, 176-186. [CrossRef]

24. Fields, K. Demand for the gastronomy tourism product. Motivational factors. In Tourism and Gastronomy; Hjalager, A.M., Richards, G., Eds.; Routledge: London, UK, 2002; pp. 36-50.

25. Kim, Y.G.; Eves, A.; Scarles, C. Building a model of local food consumption on trips and holidays: A grounded theory approach. Int. J. Hosp. Manag. 2009, 28, 423-431. [CrossRef]

26. Sims, R. Putting place of the menu: The negotiation of locality in UK food tourism, from production to consumption. J. Rural Stud. 2010, 26, 105-115. [CrossRef]

27. Björk, P.; Kauppinen-Räisänen, H. Exploring the multi-dimensionality of travellers' culinary-gastronomic experiences. Curr. Issues Tour. 2016, 19, 1260-1280. [CrossRef]

28. Babolian-Hendijani, R. Effect of food experience on tourist satisfaction: The case of Indonesia. Int. J. Cult. Tour. Hosp. Res. 2016, 10, 272-282. [CrossRef]

29. Dimitrovski, D.; Crespi-Vallbona, M. Urban food markets in the context of a tourist attraction-La Boqueria market in Barcelona, Spain. Tour. Geogr. 2018, 20, 397-417. [CrossRef]

30. Millán-Vazquez de la Torre, M.G.; Arjona-Fuentes, J.N.; Amador-Hidalgo, J. Olive oil tourism: Promoting rural development in Andalusia (Spain). Tour. Manag. Perspect. 2017, 21, 100-108. [CrossRef]

31. Folgado-Fernández, J.A.; Campón-Cerro, A.M.; Hernández-Mogollón, J.M. Potencial of olive oil tourism in promoting local quality food products: A case study of the region of Extremadura, Spain. Heliyon 2019, 5, e02653. [CrossRef]

32. Balderas-Cejudo, A.; Patterson, I.; Leeson, G.W. Senior foofies: A developing niche market in gastronomic tourism. Int. J. Gastron. Food Sci. 2019, 16, 100152. [CrossRef]

33. Björk, P.; Kauppinen-Räisänen, H. A destination's gastronomy as a means for holiday well-being. Br. Food J. 2017, 119, 1578-1591. [CrossRef]

34. Quan, S.; Wang, N. Towards a structural model of the tourist experience: An illustration from food experiences in tourism. Tour. Manag. 2004, 25, 297-305. [CrossRef]

35. Taar, J. The best culinary experience. Factors that create extraordinary eating episodes. Procedia-Soc. Behav. Sci. 2014, 122, 145-151. [CrossRef]

36. De Salvo, P.; Hernández-Mogollón, J.M.; Di Clemente, E.; Calzati, V. Territory, tourism and local products. The extra virgin oil's enhancement and promotion: A benchmarking Italy-Spain. Tour. Hosp. Manag. 2013, 19, $23-34$.

37. Desmet, P.M.A.; Schifferstein, H.N.J. Sources of positive and negative emotions in food experience. Appetite 2008, 50, 290-301. [CrossRef]

38. Berbel-Pineda, J.M.; Palacios-Florencio, B.; Ramírez-Hurtado, J.M.; Santos-Roldán, L. Gastronomic Experience as a factor of motivation in the tourist movements. Int. J. Gastron. Food Sci. 2019, 18, 100171. [CrossRef]

39. Agyeiwaah, E.; Otoo, F.E.; Suntikul, W.; Huang, W.J. Understanding culinary tourist motivation, experience, satisfaction, and loyalty using a structural approach. J. Travel Tour. Mark. 2019, 36, 295-313. [CrossRef]

40. Rodríguez-Gutiérrez, P.; González Santa-Cruz, F.; Pemberthy, L.E.; López-Guzmán, T. Gastronomic satisfaction of the tourist: Empirical study in the Creative City of Popayán, Colombia. J. Ethn. Foods 2020, 7, 8. [CrossRef]

41. Pérez-Gálvez, J.C.; López-Guzmán, T.; Córdoba, F.; Medina-Viruel, M.J. Gastronomy as an element of attraction in a tourist destination: The case of Lima, Perú. J. Ethn. Foods 2017, 4, 254-261. [CrossRef] 
42. Orgaz-Agüera, F.; López-Guzmán, T. Análisis del perfil, motivaciones y valoraciones de los turistas gastronómicos. El caso de la República Dominicana. ARA J. 2015, 5, 43-52.

43. Moral-Cuadra, S. Turismo y Desarrollo Sostenible en la Frontera Norte Dominico-Haitiana: Descripción de la Oferta y Análisis de la Demanda. Ph.D. Thesis, Universidad de Córdoba, Córdoba, Colombia, 2017.

44. Finn, M.; Elliott-White, M.; Walton, M. Tourism and Leisure Research Methods: Data Collection, Analysis and Interpretation; Pearson Education: Harlow, UK, 2000.

45. Norusis, M.J. SPSS. Stadistical Data Analysis; SPSS Inc.: Chicago, IL, USA, 1993.

46. Nunnally, J.; Bernstein, I. Psychometric Theory; McGraw-Hill: New York, NY, USA, 1994.

47. Chin, W.W. How to write up and report PLS analyses. In Handbook of Partial Least Squares; Esposito Vinci, V., Chin, W.W., Henseler, J., Wang, H., Eds.; Springer: Berlin, Germany, 2010; pp. 655-690.

48. Fornell, C.; Bookstein, F.L. Two Structural Equation Models: LISREL and PLS Applied to Consumer Exit-Voice Theory. J. Mark. Res. 1982, 19, 440-452. [CrossRef]

49. Reinartz, W.; Haenlein, M.; Henseler, J. An empirical comparison of the efficacy of covariance-based and variance-based SEM. Int. J. Res. Mark. 2009, 26, 332-344. [CrossRef]

50. Cassel, C.; Hackl, P.; Westlund, A.H. Robustness of partial least-squares method for estimating latent variable quality structures. J. Appl. Stat. 1999, 26, 435-446. [CrossRef]

51. Henseler, J. Partial least square path modelling: Quo vadis? Qual. Quant. 2018, 52, 1-8. [CrossRef]

52. Henseler, J.; Hubona, G.; Ray, P.A. Using PLS path modelling in new technology research: Updated guidelines. Ind. Manag. Data Syst. 2016, 116, 2-20. [CrossRef]

53. Hu, L.-T.; Bentler, P.M. Fit indices in covariance structure modelling; Sensivity to underparameterized model misspecification. Psychol. Methods 1998, 3, 424-453. [CrossRef]

54. Williams, L.; Vandenberg, R.J.; Edwards, R.J. Structural equation modeling in management research: A guide for improved analysis. Acad. Manag. Ann. 2009, 3, 543-604. [CrossRef]

55. Hair, J.F.; Hult, G.T.; Ringle, C.M.; Sarstedt, M. A Primer on Partial Least Squares Structural Equation Modeling (PLS-SEM); Sage: Thousand Oak, CA, USA, 2017.

56. Carmines, E.G.; Zeller, R.A. Reliability and Validity Assessment; Sage University: Beverly Hills, CA, USA, 1979.

57. Bagozzi, R. Structural equation models in marketing research. In First Annual Advanced Research Techniques Forum; Neal, W.D., Ed.; American Marketing Association: Chicago, IL, USA, 1994.

58. Diamantopoulos, A.; Siguaw, J.A. Formative versus Reflective Indicators in Organizational measure development: A comparison and Empirical Illustration. Br. J. Manag. 2006, 17, 263-282. [CrossRef]

59. Roberts, N.; Thatcher, J. Conceptualizing and testing formative constructs: Tutorial and annotated example. ACM SIGMIS Database 2009, 40, 3-39. [CrossRef]

60. Dijkstra, T.; Henseler, J. Consistent Partial Least Square Path Modeling. MIS Q. 2015, 39, 297-316. [CrossRef]

61. Chin, W.W. Issues and opinion on Structural Equation Modeling. MIS Q. 1998, 22, 7-16.

62. Fornell, C.; Larcker, D.F. Evaluating structural equation models with unobservable variables and measurement error. J. Mark. Res. 1981, 18, 39-50. [CrossRef]

63. Stone, M. Cross-validatory choice and assessment of statistical predictions. J. R. Stat. Soc. 1974, 36, 111-147. [CrossRef]

64. Geisser, S. The Predictive Sample Reuse Method with Applications. J. Am. Stat. Assoc. 1975, 70, 320-328. [CrossRef]

65. Streukens, S.; Leroi-Werelds, S. Bootstrapping and PLS-SEM: A step-by-step guide to get more out of your bootstrap results. Eur. Manag. J. 2016, 34, 618-632. [CrossRef]

66. Grybovych, O.; Lankford, J.; Lankford, S. Motivations of wine travelers in rural Northeast Iowa. Int. J. Wine Bus. Res. 2013, 25, 285-309. [CrossRef]

67. Khan, A.; Bibi, S.; Lorenzo, A.; Lyu, J.; Babar, Z.U. Tourism and development in developing economies: A policy Implication perspective. Sustainability 2020, 12, 1618. [CrossRef]

68. Prevolsek, B.; Maksimovic, A.; Puska, A.; Pazek, K.; Zibert, M.; Rozman, C. Sustainable development of ethno villages in Bosnia and Herzegovina-A multi criterio assessment. Sustainability 2020, 12, 1399. [CrossRef]

(C) 2020 by the authors. Licensee MDPI, Basel, Switzerland. This article is an open access article distributed under the terms and conditions of the Creative Commons Attribution (CC BY) license (http://creativecommons.org/licenses/by/4.0/). 